Article

\title{
Achieving Successful River Restoration in Dense Urban Areas: Lessons from Taiwan
}

\author{
Rung-Jiun Chou \\ Department of Landscape Architecture, Chung Yuan Christian University, Taoyuan City 32023, Taiwan; \\ rungjiun@gmail.com; Tel.: +886-3-2656409
}

Academic Editor: Xiangzheng Deng

Received: 23 July 2016; Accepted: 7 November 2016; Published: 10 November 2016

\begin{abstract}
A paradigm shift in river management practice is underway, from a hard engineering-dominated emphasis that endeavours to control water, to a multi-functionality-framed approach that strives to restore a river's ecology, scenery and ecosystem services. In Taiwan, the Laojie River in Taoyuan City, where a channelized and piped urban river was recently transformed into an accessible, linear green infrastructure feature, is widely regarded as the first extensive and successful river restoration project in Taiwan's densely-urbanized, flood-prone areas, yet its actual performance is rarely examined in any depth. Through in-depth interviews, fieldwork and a review of government documents, this paper presents findings on the practical factors involved in the practice of river restoration and their implications for urban river management. First, local people support river restoration with de-culverting, but potential flooding is a concern that results from different flood-risk perceptions and ineffective flood-risk communication between the government and public. Second, a mix of hard and soft edges to the watercourse improves the riverside landscapes in a densely-urban, flood-prone area. Third, due to a lack of basin-wide supporting sanitary sewer systems, a combination of on-site gravel contact oxidation treatment systems and riverside sewage-intercepting facilities still fails to improve the river water quality. Fourth, people's positive attitudes towards river restoration are largely associated with landscape aesthetics and recreational value, rather than water quality and biodiversity. It is revealed that using the Cheonggyecheon Stream in South Korea as a frame for river restoration seems effective in providing local people with an example of successful river restoration, based mainly on flood prevention and recreational and aesthetic improvement. Moreover, the effective flood-risk communication is mainly reliant on an intelligible presentation of related information to the general public. Practical, continuous and extensive public participation, with various types of involvement and resources along with a solid system of social objectives by which to assess the outcome, is central to the social aspect of river restoration.
\end{abstract}

Keywords: river restoration; multi-functionality; flood risk; green infrastructure; landscape management

\section{Introduction}

The United Nations (UN) Intergovernmental Panel on Climate Change (IPCC), a leading international scientific body, indicates that river flooding is a recent widespread impact of climate change, and that increasing trends towards extreme precipitation and discharge into catchments imply greater flood risk within river corridors [1]. Especially, high and increasing population density urban areas are more vulnerable to the consequences of climate change [2]. Simply put, global warming and changing climatic patterns have far-reaching environmental impacts, particularly for densely-urban river spaces.

To secure sustainable environmental management and flood prevention, multi-functional river developments are being promoted internationally [3]. Replacing traditional channels and culverts to increase the flow capacity [4] with a multi-functional approach to water management emphasizes the 
role of urban rivers as a multi-functional open-space network [5] using green infrastructure practices to deliver ecosystem services [6]. The key benefit is to buffer the aquatic environment against the effects of climate change and population growth whilst securing sustainable water management [7]. River corridors are seen as unique resources with multiple environmental and social purposes, such as supplying clean water, adjusting discharge and temperature, improving the groundwater resources, supporting biodiversity and enshrining aesthetic, recreational and cultural values [8].

Despite this, the urbanization process poses greater risk and uncertainty when managing water, e.g., surface run-off and water pollution [9], which extensively affect the built and natural environment. Many urban watercourses are lined with high concrete parapets and culverted in order to remove water quickly, hide unsightly water pollution and facilitate other uses (e.g., parking and building plots) [10]. Nevertheless, rerouting water into underground culverts is problematic as it confines drainage capacity, raises flood risk downstream, harms aquatic ecosystems, degrades water quality and makes water space invisible to people [11,12]. Thus, the importance of opening up underground culverts ("de-culverting" or "daylighting") [13] is increasingly prevalent internationally [14].

River management has experienced a paradigm shift from a long-established debate about flood defence to a more open-ended debate on river restoration [15]. Although this debate is current among river specialists, in practice it seems to indicate that river restoration means different things to different people [16]. In terms of scale and scope, it can be a complete structural and functional return to the pre-disturbance state, a recovery of the partly functional and/or structural conditions of rivers (i.e., rehabilitation), a recovery of the natural state of a river ecosystem without really aiming at the pristine, pre-disturbance state (i.e., renaturalization), or an improvement of the present state of rivers and their surrounding areas with the intention of enhancing their ecological, social, economic or aesthetic features (i.e., enhancement) [17]. While it is unrealistic to expect any restoration approach will achieve a pristine state for a river, the possibilities of restoration should be determined to indicate attainable targets $[18,19]$. For example, improved water quality, riparian management, in-stream habitats, fish passage, bank stabilization, aesthetics, recreation, education, and stormwater management are frequently stated as goals for river restoration in the USA [20]. Many river restoration projects in the United Kingdom are modest in scale and limited in scope aiming only at relatively restricted enhancements to the environment [15]. To put it simply, there are three general types of river restoration goals: restoration of species, restoration of landscapes and restoration of ecosystem services [21]. These objectives can obviously differ in complexity, yet the importance is to understand what expectations of restoration are feasible in terms of the five river restoration dimensions: conceptual, spatial, temporal, technological and presentational [22].

As realistic goals are fundamental to progress towards favourable outcomes [23], the meaning of success for river restoration is project-dependent. There are different methods for assessing river restoration success that mainly relate to the ecological attributes of rivers but socio-economic aspects are also considered (e.g., [24]). However, the assessment is often centred on measurable, scientifically objective parameters with more subjective aspects (e.g., landscape aesthetics and recreational value) often being overlooked even though they play a crucial role in the perception and communication of successful restoration [25]. Overall, the most effective river restoration projects may lie at the intersection of the three primary axes of success: (1) stakeholder success that reflects human satisfaction with restoration outcome (e.g., aesthetics, economic benefits and recreation); (2) ecological success that shows that the desired ecosystem functions have been achieved (e.g., ecological improvement and becoming self-sustaining); and (3) learning success that reflects advances in scientific knowledge and management practices that will benefit future restoration projects (e.g., scientific contributions, management experience and improved methods) [26]. The focus of river restoration has progressively altered over time, changing from ecological integrity to wider human benefits that cover a broad range of actions aiming to improve environmental features [27].

River restoration is closely associated with flood prevention. While river restoration is framed as a measure to lessen flood risk, the challenge is that risk perception and water safety are important 
aspects for public attitudes towards changes to rivers [28]. Restoring rivers usually raises local concerns about the impact on flood prevention and community safety [29], due to the dynamic river features (e.g., the height, speed and volume of flow) that intensify the uncertainty in water management and generate potential fears about the dangers of flooding [30]. Public participation and local support is fundamental to river restoration projects. The local public frames the success or expectations of river restoration in their own terms. This in an urban setting may be mainly based on the reduction of flood risk and the improvement of recreational and aesthetic values [31]. This obviously involves multi-functional amenity outcomes for urban waters and their riparian areas.

Taiwan is typhoon-affected, flood-afflicted and located in East Asia. The popularity of hard-engineered watercourses as well as the problems of wastewater contamination are issues in its densely-urbanized areas [32]. De-culverting the Laojie River in densely-urbanized Taoyuan City is a recent significant example of improving a river environment $[33,34]$ that intends to transform a channelized, culverted, flood-control watercourse into a multi-functional resource by focusing on riverside landscape and water quality improvements [35]. Beginning in 2011, the currently on-going river improvement plan aims at replacing the infrastructure established for drainage, transport and other city developments, with a green, publicly-accessible, alternative corridor [36].

While the Laojie River project is widely considered to be the first extensive and successful river restoration project in a highly-urbanized, flood-prone area in Taiwan, its actual performance is rarely examined in any depth. This paper presents findings on the practical factors involved in the practice of river restoration and their implications for urban river management. The significance of the case study is to better-inform the practical considerations while implementing river restoration with culvert-removal in dense, flood-prone, East Asian cities. In the following, the paper reviews urban river management in Taiwan and explains the methods of collecting and analysing the data and results in this study. The important issues concerning river restoration through de-culverting in densely-urban, flood-prone areas are then discussed and conclusions drawn.

\section{Urban River Management in Taiwan}

Taiwan's physical environment, topography and climate are the main natural factors influencing the management of urban rivers, many of which are short, steep and fast-flowing and are greatly affected by the rainfall pattern [37]. The rainy season is from May to October [38] with the peak from mid-July to mid-August [39]. Frequent thunderstorms and typhoons, occurring mainly in July, August and September [38], often cause floods, fatalities and damage to riverside property. Moreover, rapid urbanization, with 3885 persons $/ \mathrm{km}^{2}$ at the end of 2014 [40], has extensively changed natural river patterns and encroached on riverside buffer strips to increase development land. Addressing these complex, combined, environmental impacts is fundamental to Taiwan's urban river management. The evolution of Taiwan's contemporary urban river management falls into three periods [41]:

(1) Flood defence as the single objective (before 1996);

(2) Green beautification and water accessibility (1996-2001); and

(3) Ecologically-oriented river engineering (after 2001).

Conventional hard-engineering measures, e.g., underground culverts, concrete embankments and high flood walls, with the single flood-control purpose of rapidly removing water, dominated river space design pre-1996 [42]. Today, typical urban river landscapes involve substantial different-sized concrete parapets straightjacketing natural waterways, where water is hidden or fenced from people, because of potential danger (e.g., sheer drops) or eyesores (e.g., water pollution).

With growing concerns about sustainable environments in the mid-1990s, Taiwan started to reconsider watercourse development. In 1998, an important plan for green beautification of rivers and slopes was administered by the government's Soil and Water Conservation Bureau (SWCB) [43]. With the intention of reconnecting people to nature, a key task in this period was to promote the ideas of green beautification and water accessibility within a river corridor [44]. Nevertheless, in terms of 
managing rivers, the actual effect was limited since engineering solutions, e.g., cycleways, dominated riverside landscape facilities [45]. Additionally, the strategy of quasi-naturalistic landscaping design was gradually adopted for rehabilitating urban culverted rivers, e.g., the Mei Stream in the City of Taichung [32], where an upper-level man-made stream was created to provide recreational use and riverine environment, while the real stream remained underground to carry riparian rainwater and wastewater downstream. This double-layer stream layout is the subject of debate within urban river management.

Recently, the government has further promoted ecologically-oriented river engineering, such as the central policy of the Water and Green Construction Plan (WGCP) from 2002 to 2007, to encourage river development towards flood protection, biodiversity and recreation [46]. However, although the theory and practice of this approach has been locally developed [47-49], this new agenda has been unsuccessful $[41,50]$. Besides river pollution, a lack of confidence in the system of ecologically-oriented river engineering has become a fundamental issue, particularly for those living in flood-prone areas [42].

Flood risk and water pollution have been major concerns for Taiwan's urban river development. Extreme weather conditions and the urbanization process increase environmental threats to well-being, public health and ecology for rivers located in densely-developed areas. This shows that improving a hard-engineered and highly-polluted, densely urban river is still a difficult task for Taiwan's river specialists.

\section{Methods}

The research was conducted from August 2014 to September 2015 with data coming from in-depth interviews, fieldwork and a review of government documents. In-depth interviews took place with one neighbourhood leader (IV1) and three senior practitioners (IV2-IV4) with practical knowledge and experience of improving urban rivers and a deep understanding of the Laojie River redevelopment. Interviewee identification codes ensured confidentiality and anonymity. Each interviewee was asked three central open questions: what are the issues affecting the restoration of the urban river in question, what are the experiences from the de-culverting of its culverted stretch, and what are the challenges and opportunities as it evolves towards being a multi-functional urban river? All interviews were recorded for transcription, coding and analysis.

In terms of fieldwork, a typology of Taiwan's densely urban rivers was firstly developed by the researcher in order to classify and map study areas that are representative of the major types of urban river reaches (Table 1). Rivers were classified into four spatial types: recreation, transport, mixed use property and underground culverts. The stretch selected for study (Figure 1) covers these four types and provides an appropriate context for examining urban river restoration with culvert-removal.

An assessment checklist was then established based on a review of the literature on multi-functional urban river space design [3,14,32,51] (see Appendix A). Accessibility, diversity, enjoyment and sustainability, as the four key concepts for designing multi-functional urban rivers to achieve multiple recreational, social and environmental roles, formed the structure of the assessment checklist. The checklist comprised 18 open questions and was grouped into six topics, namely: (1) accessibility; (2) activities; (3) public facilities; (4) environmental quality; (5) ecological value; and (6) flood prevention. This research tool was used to systematically and effectively guide the evaluation. 
Table 1. A typology of Taiwan's dense urban rivers, based on the author's fieldwork and literature review $[10,52,53]$.

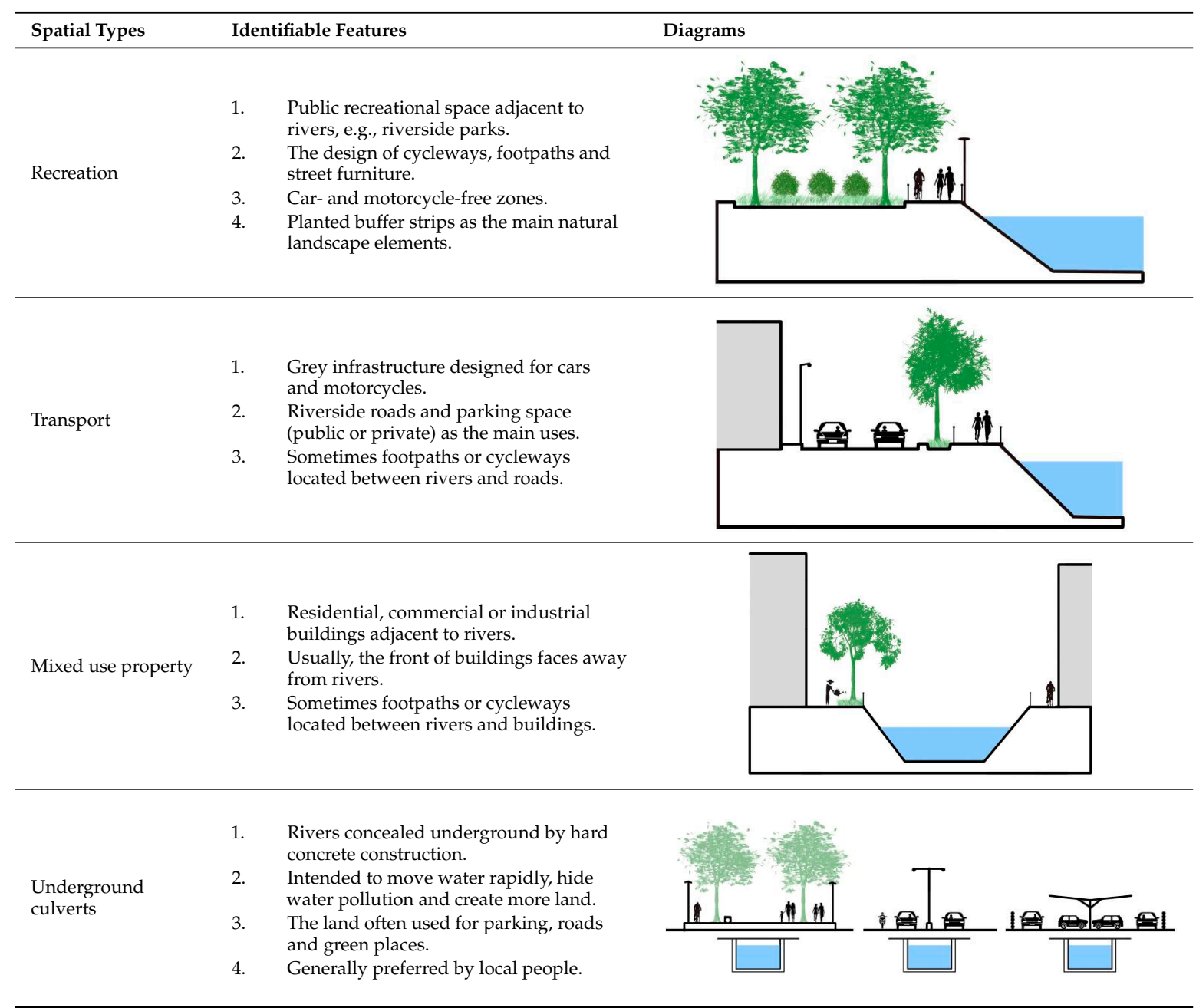
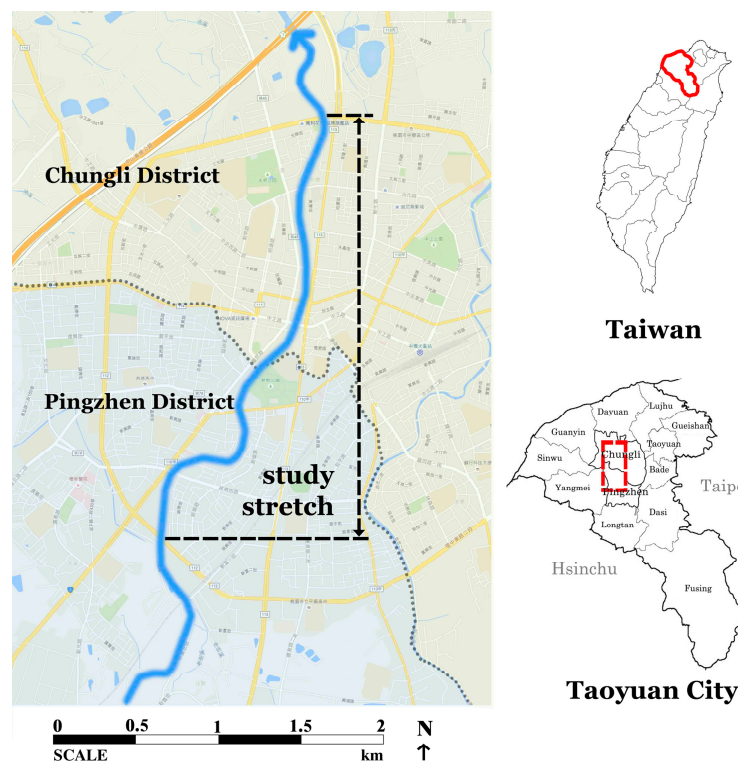

Taiwan

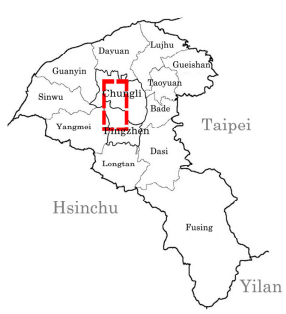

Taoyuan City

Figure 1. Location of the Laojie River with the study stretch demarcated. 
The assessment involved the measurement of the percentages of the four spatial types (i.e., Table 1) and the examination of the 18 open questions within the selected stretch of the Laojie River. Its important issues were recorded with field notes and photographs. Figure 2 shows the locations of the four river spatial types and Figures 3-8 outline the assessment outcomes. Finally, the important case-related official reports, news reports, articles and books were reviewed, in order to strengthen the analysis of the study.

The field notes with the assessment outcomes constitute the main part of the analysis, supported by participants' accounts providing qualitative data, related photographs and river cross-section drawings serving as visual evidence, and relevant documents providing more detailed information. All quotations are verbatim labelled with ID codes, and those marked with an asterisk (e.g., IV2*) indicate paraphrased comments.

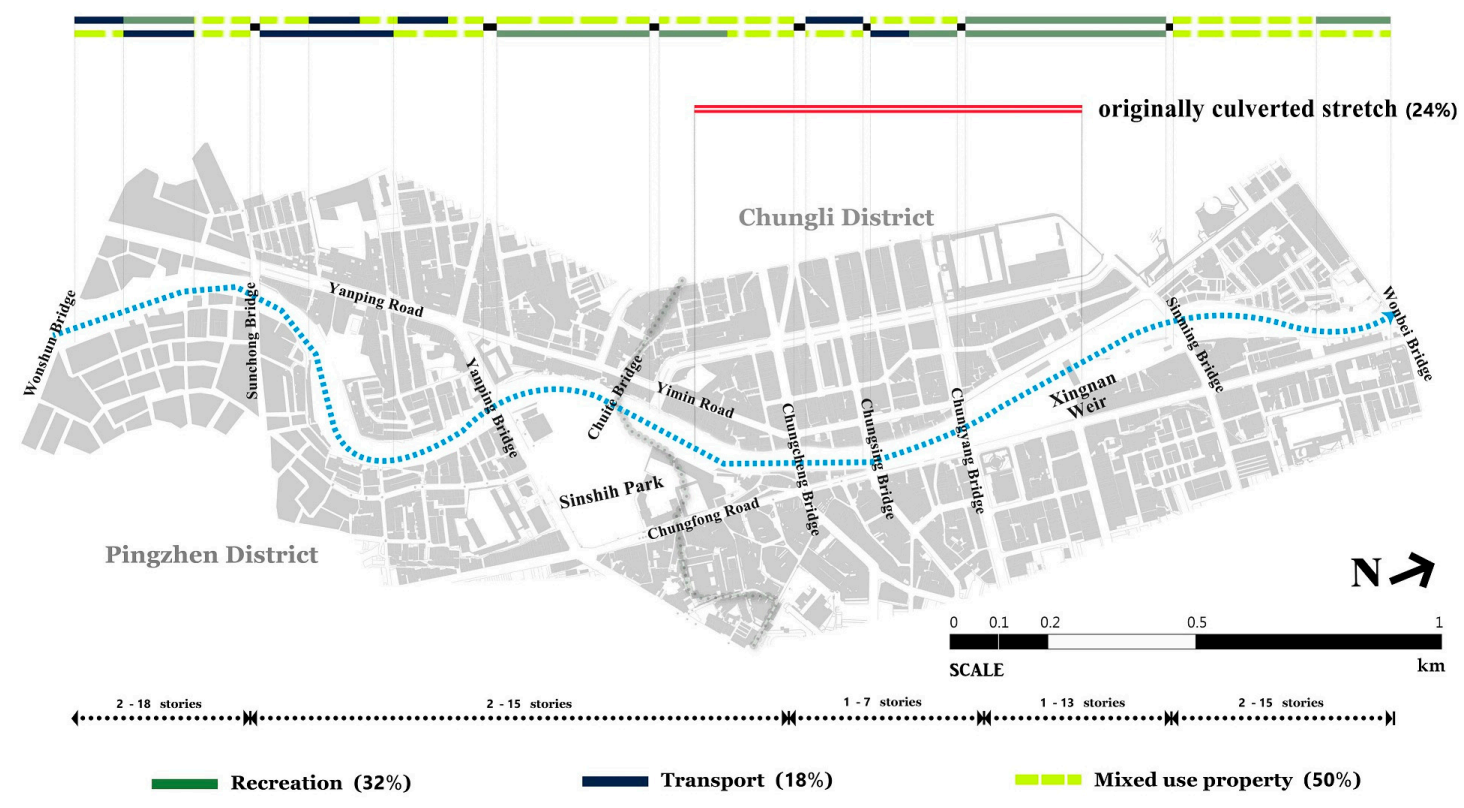

Figure 2. The locations of the four river spatial types within the Laojie River.

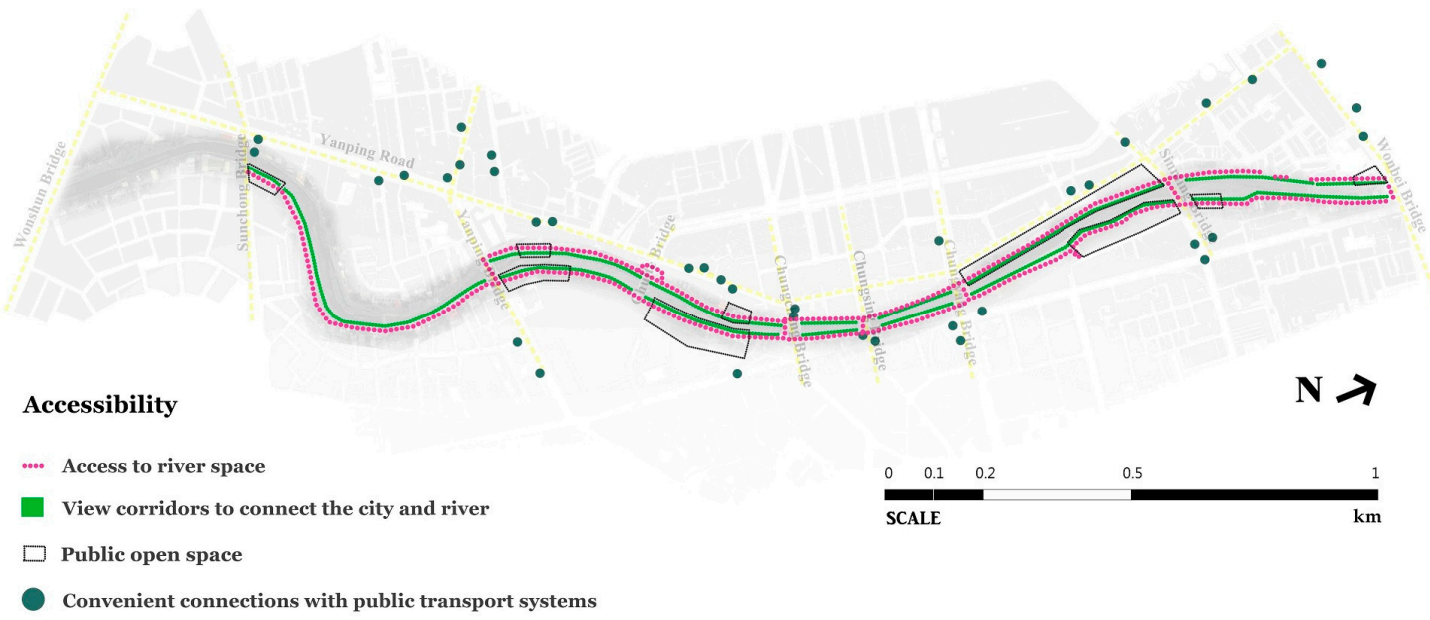

Figure 3. The improved accessibility (four open questions) within the Laojie River. 


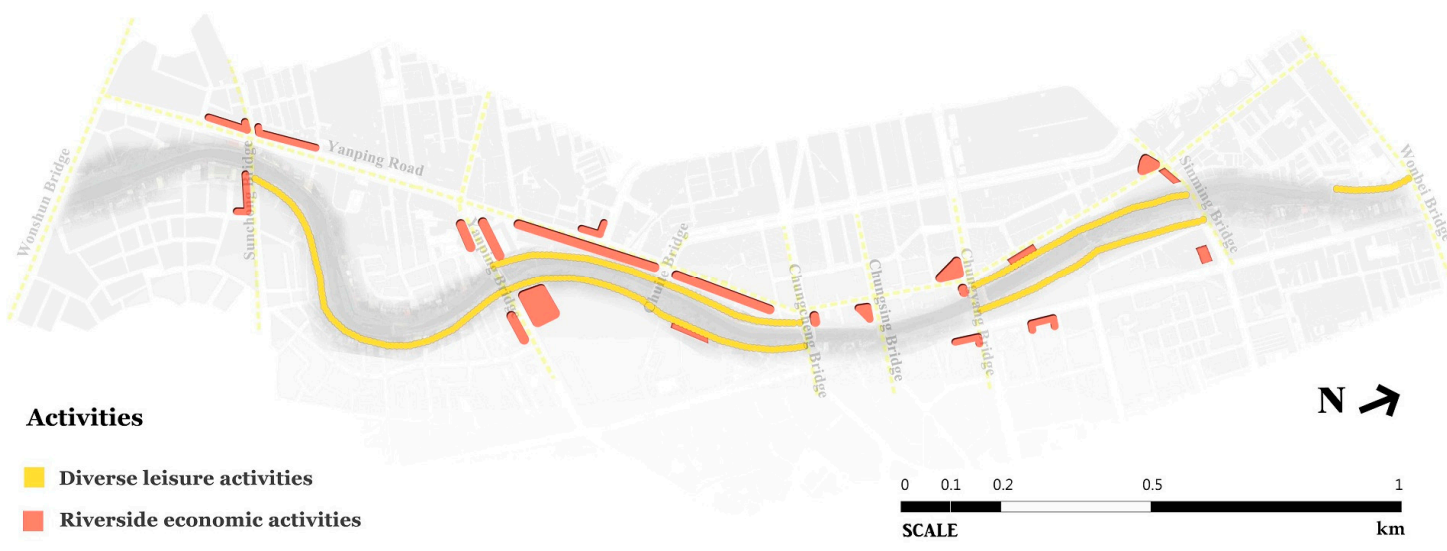

Figure 4. The improved activities (two open questions) within the Laojie River.

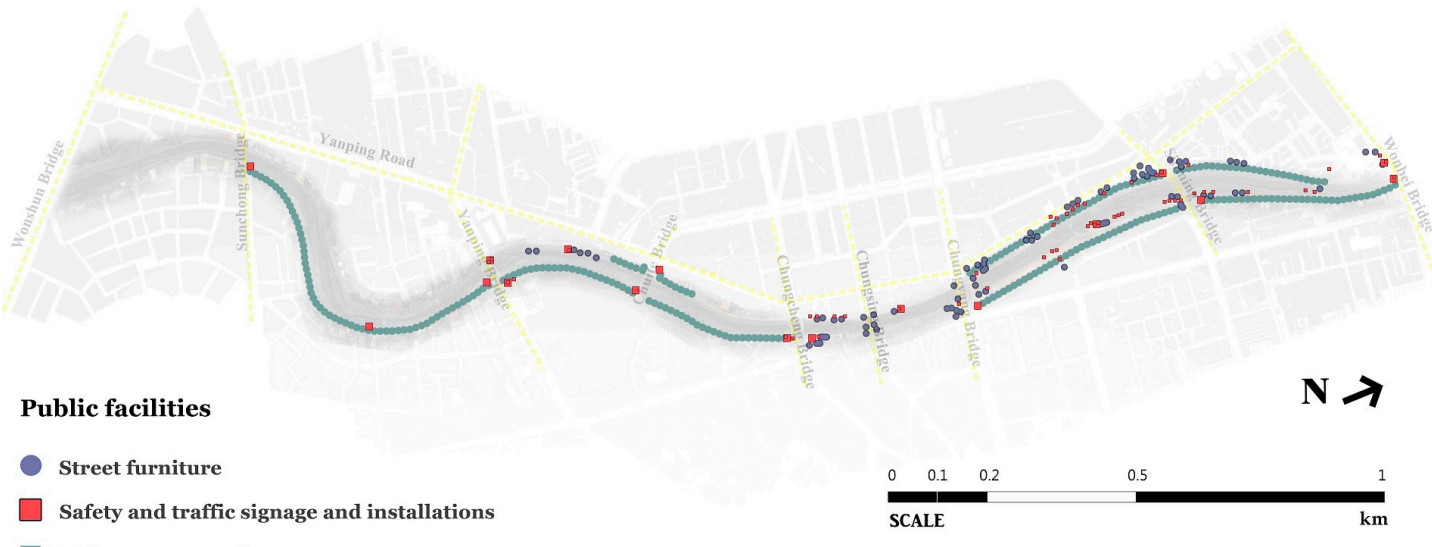

Maintenance services

Figure 5. The improved public facilities (three open questions) within the Laojie River.

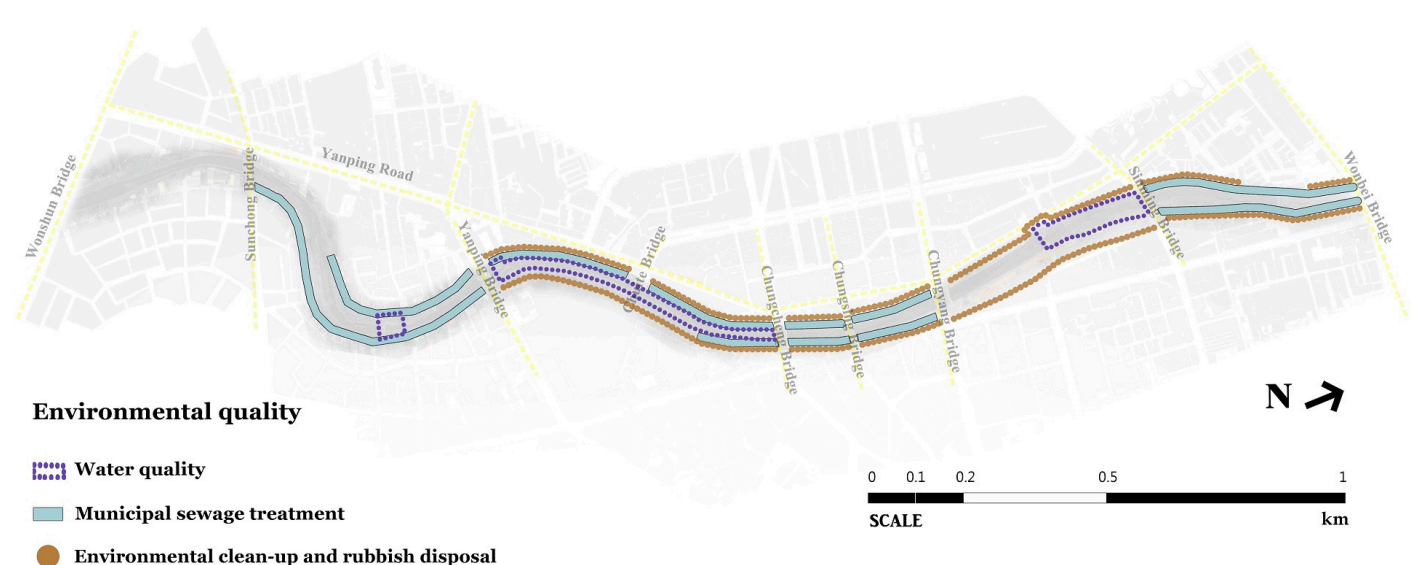

Figure 6. The improved environmental quality (three open questions) within the Laojie River. 


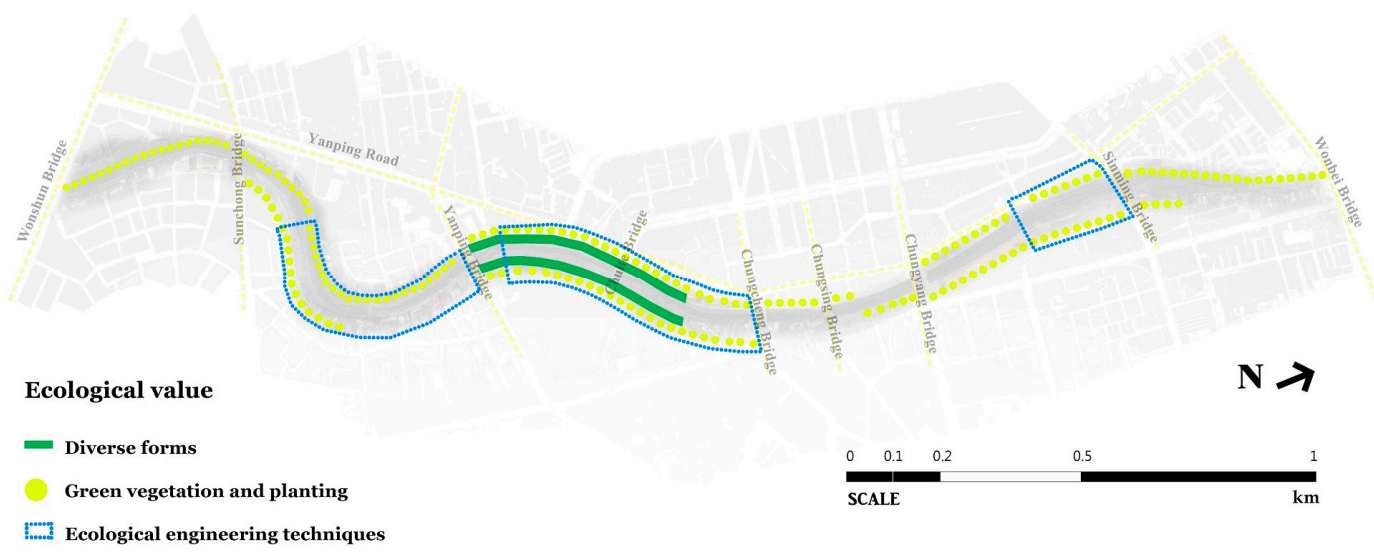

Figure 7. The improved ecological value (three open questions) within the Laojie River.

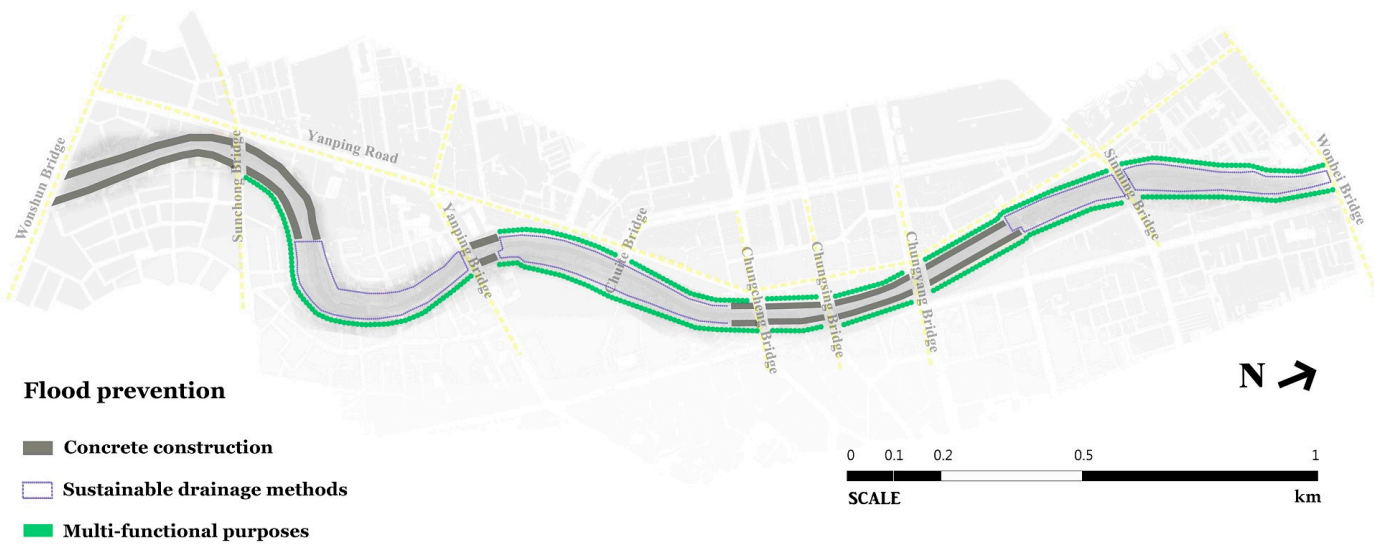

Figure 8. The improved flood prevention (three open questions) within the Laojie River.

\section{Results}

Taoyuan City contains $37 \mathrm{~km}$ of the Laojie River flowing south-north. It is slightly tidal with a catchment area of $82 \mathrm{~km}^{2}$ [54]. The $3 \mathrm{~km}$ study stretch (Figures 1 and 2) flows through the dense old city districts of Pingzhen and Chungli. The width is $35-80 \mathrm{~m}$ and the water $1.35-4.72 \mathrm{~m}$ deep [55]. The 725 m-long originally culverted stretch (circa $24 \%$ of the study stretch) is located in the central area, where in 1997 extensive illegal privately-built constructions provided commercial and parking space, hid water pollution and rapidly drained the river water [56] (Figure 9).

Due to growing environmental concerns about flooding, water quality and riverside landscape [57], TYCG has, since 2011, implemented a cross-sectoral regeneration policy (the Laojie River Improvement Plan) with the aim of developing a "Cheonggyecheon Stream of Taoyuan" [35]. The plan involves six government agencies (Water Resources, Urban Development, Environmental Protection, Agriculture, Education, and Cultural Affairs) and two local authorities (Pingzhen and Chungli Districts). The key works include de-culverting (by Water Resources in 2011), riverside landscape improvement (by Urban Development since 2012) and on-site treatment and sewage-intercepting facilities (by Environmental Protection since 2011) ([58], IV3*).

Fieldwork estimates (Figure 2) indicate that, after de-culverting, 50\% of the remaining property is mixed use, $32 \%$ is for recreation and $18 \%$ for transport. Mixed-use property comprises ordinary riverside houses, large-scale housing, shops and small factories. Interestingly, unlike most pre-2011 developments that placed the river behind buildings (Figure 10), the post-2011 housing developments face the river with access roads to the rear, providing open space and safe pedestrian and cycleways between the river and buildings (Figure 11). 


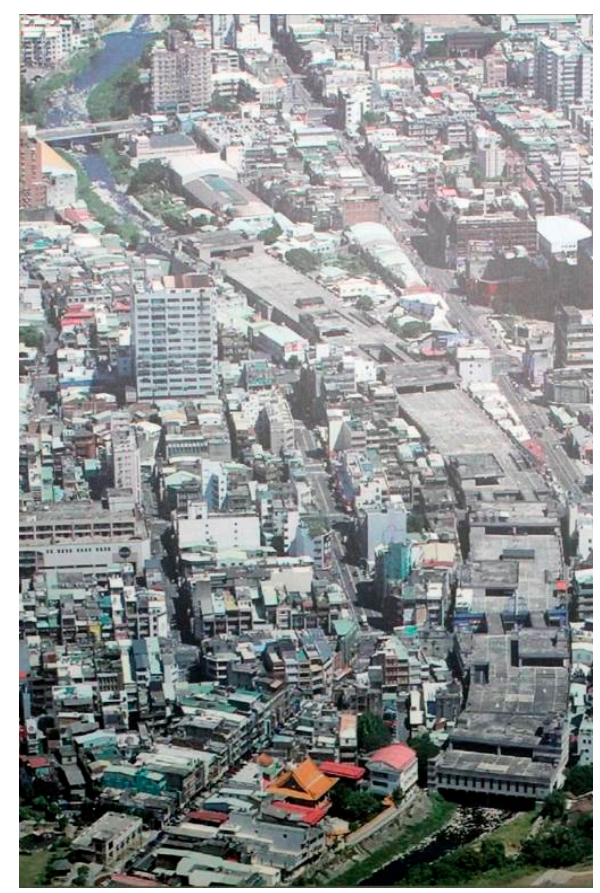

Figure 9. The aerial view of the Laojie River's culverted area before improvement [35].

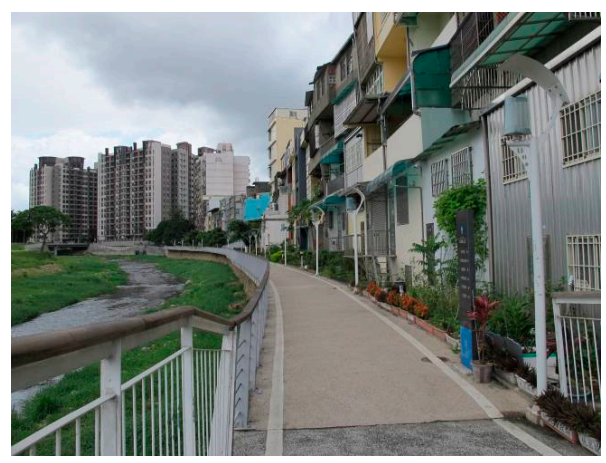

Figure 10. The Laojie River running behind pre-2011 ordinary houses near Chuite Bridge.

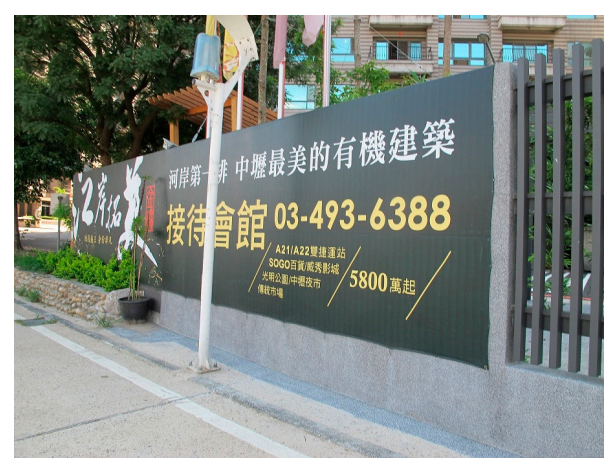

Figure 11. The Laojie River running at the front of a new housing development with its real estate advertising poster near Sinming Bridge. The price (NT \$58 million (about US \$1.83 million) has risen by $20 \%-50 \%$.

The improvements have developed public recreational places (e.g., Sinshih Park) with linear open space alongside between Chungyang and Sinming Bridges. Notably, Sinshih Park shows a more 
natural, irregular, softer water's edge (IV2*] (Figure 12), unlike the linear riverside open space with its hard water's edge combined with recreational cycleways, footpaths and street furniture (Figure 13). The riverside area of Sinshih Park shows an attempt to strike a better balance between flood defence, ecological functions and recreational uses (IV3* ${ }^{*}$ IV4*].

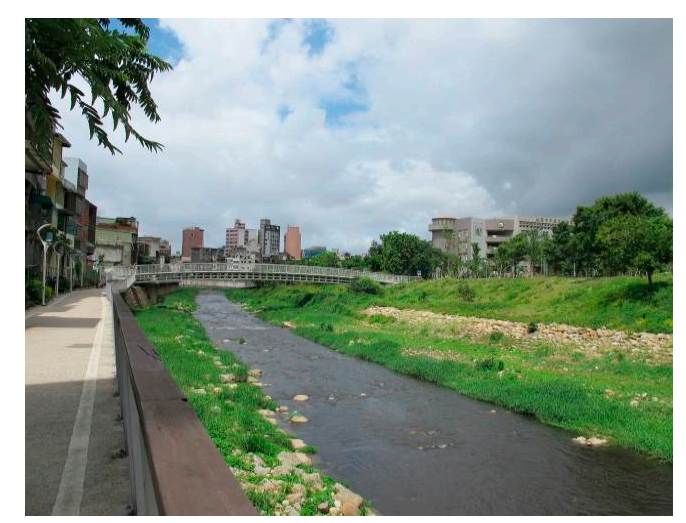

Figure 12. Planted buffer strips as the main natural river landscape elements around Sinshih Park.

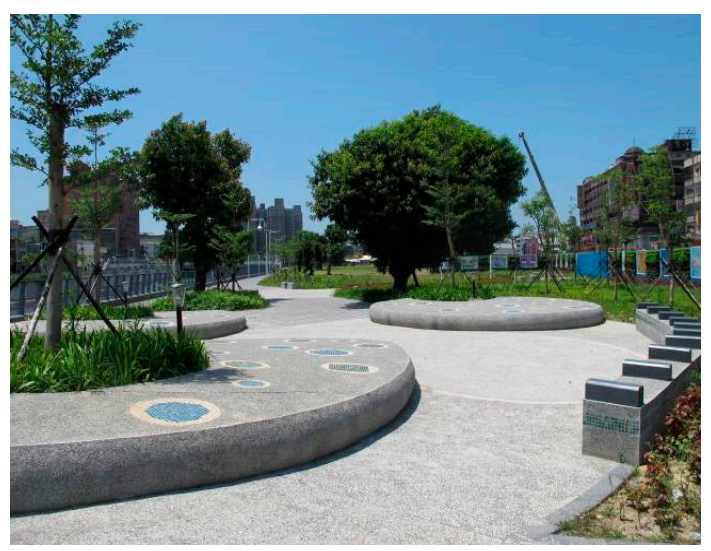

Figure 13. Recreational cycleways, footpaths and street furniture near Chungyang Bridge.

Transportation functions dominate between Wonshun and Yanping Bridges. This river stretch lies outside the first priority areas of the 2011 river improvement plan ([36], IV2* IV3*). This confirms the fieldwork results that show largely unchanged grey infrastructure of roads and public-private vehicle parking spaces (Figure 14). However, currently some small-scale improvements with footpaths and cycleways built along riverside roads are under construction (Figure 15).

The improvements contain three parts: (1) de-culverting; (2) riverside landscape improvement; and (3) on-site treatment and sewage-intercepting facilities. First, daylighting the $725 \mathrm{~m}$ culverted stretch in 2011 was to remove the overhead buildings-the Laojie Market and its parking lot, to mitigate the growing flood risk and bring back the city's waterscape. The de-culverted river's new cross-section (Figure 16) was designed to be 35-36 $\mathrm{m}$ wide and 5-6 $\mathrm{m}$ deep with three new bridges, the Chungcheng, Chungsing and Chungyang, to meet the "100-year return period" flood prevention requirement [56]. De-culverting cost over NT \$430 million (about US \$13.6 million) for demolition and compensation [59], and over NT \$160 million (about US \$5 million) for the design and construction of the new bridges [60]. 


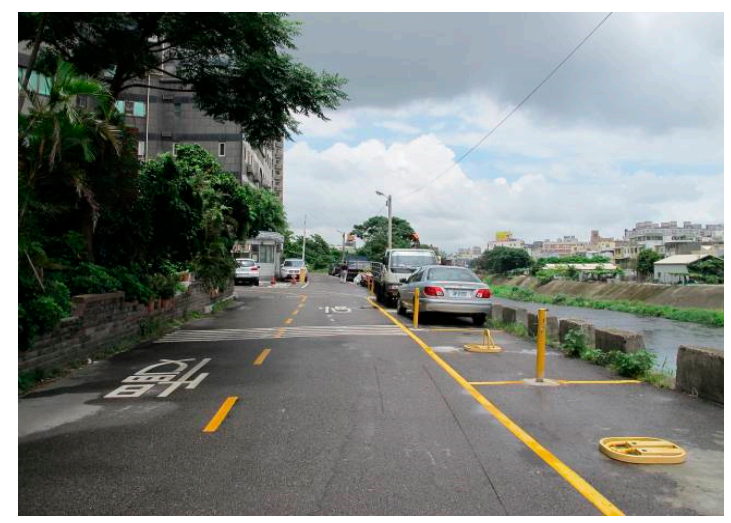

Figure 14. The riverside road and parking spaces near Wonshun Bridge remain unchanged.

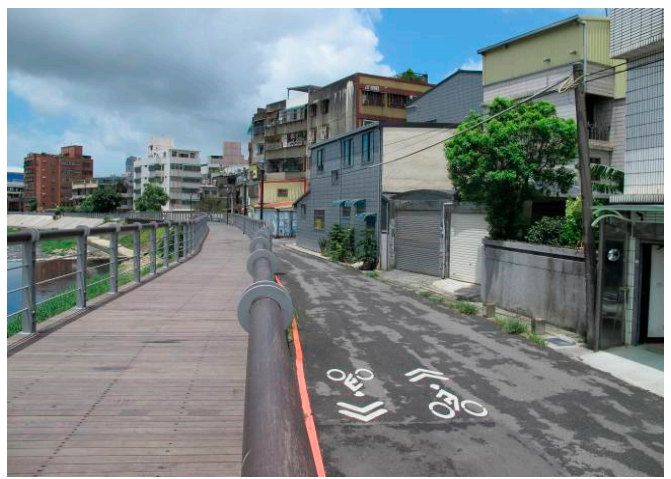

Figure 15. Small-scale improvements near Yanping Bridge include roads, footpaths and cycleways between the river and buildings.

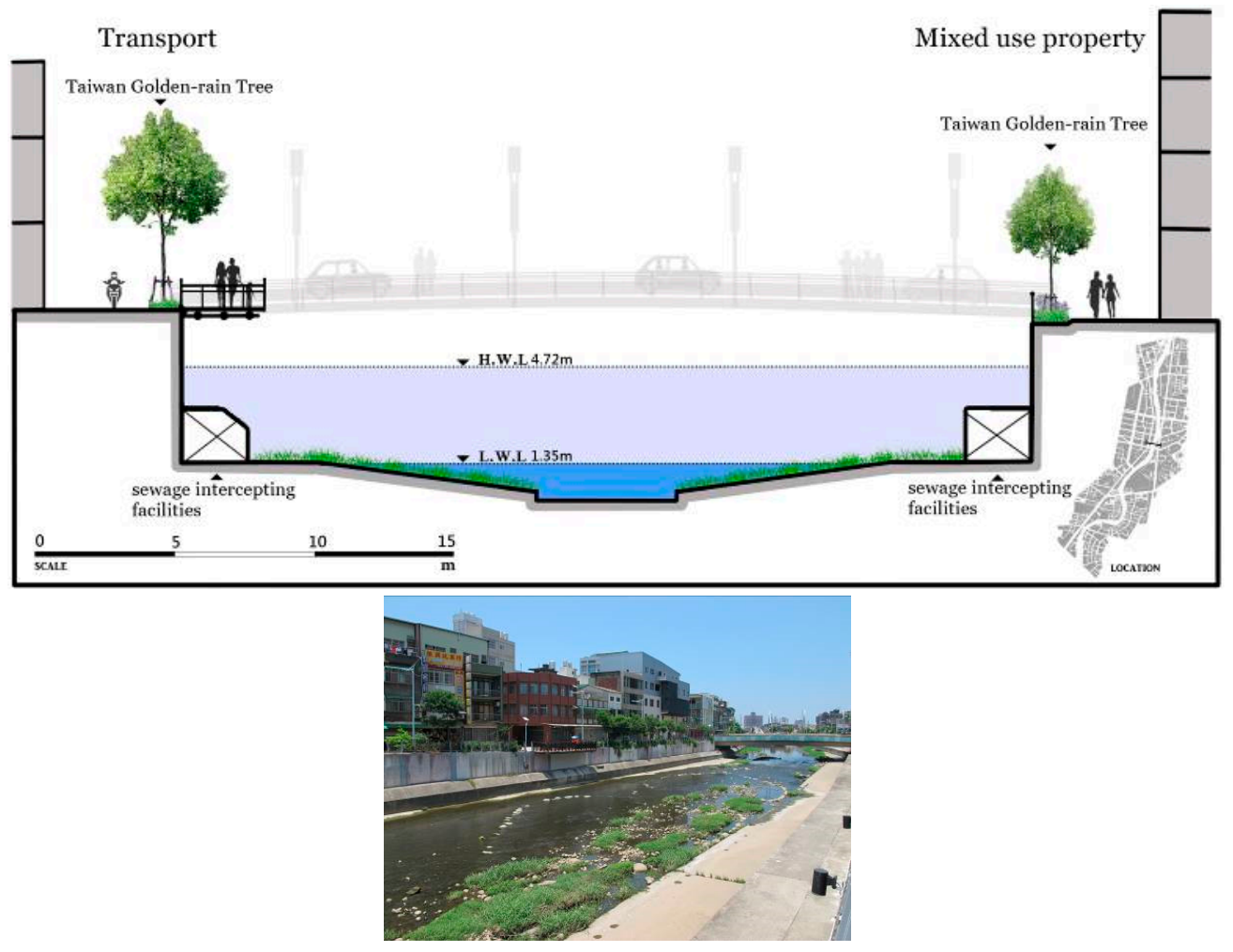

Figure 16. The new cross-section of the Laojie River around Chungcheng Bridge. 
All interviewees (IV1, IV2, IV3, IV4] indicate that the de-culverting process proved difficult, as it needed to deal with the space constraints resulting from the existing dense developments. The local authority has held over 50 open forums since 2011, in order to build public participation, consensus and support for the de-culverting and the subsequent improvements, recognizing the key role played by local participation [61]. Generally, local people support culvert-removal and river restoration to improve the environment and quality of life [62,63]. Interviewee IV1, a local neighbourhood leader, said:

"In the past, the culverting of the Laojie River was mainly for economic development and this was thought to be the right decision, although it influenced the city's riverscape. Recently, the over-water Laojie Market had not been successful and had been abandoned. It is certainly a good thing to reopen the Laojie River. After the de-culverting, we feel the landscape becomes much clearer and brighter. The river is seeing the daylight again."

Although the government paid compensation for their property losses, the United Daily News reported street protests by market stallholders on the first day of culvert demolition [64]. Concerning flood prevention, Interviewee IV2, a professor and senior landscape architect, said that "according to the information we have, such as the profiles of the new river cross-section design, the flood risk of the restored Laojie River can be better mitigated". However, some people are still concerned about potential flooding. Interviewee IV4, a senior practitioner in public participation, said:

“Culvert-removal with a 'softer' river engineering approach is seen by some people as a lower level of flood prevention than the traditional 'hard' engineering methods ... The local authority has stressed that the new Laojie River can supply the same, or even better, capability of flood prevention to riverside properties compared to the river before restoration."

This issue may arise from different perceptions of flood risk and flood mitigation measures and the miscommunication of professional language (e.g., the meaning of a "100-year return period" flood). It seems that the effectiveness of flood-risk communication by government officials is an issue. Hence, encouraging continuous, extensive, public participation to reach mutual understanding and consensus in terms of river restoration and establishing more effective flood-risk communication to develop people's risk awareness and willingness to take precautionary actions voluntarily, are essential for future river development (IV1*, IV4*].

Second, work on riverside landscape improvement has involved establishing about $3.6 \mathrm{~km}$ of cycleways, footpaths and green space between the Yanping and Wonbei Bridges combined with a lighting system [56]. According to fieldwork, the improved performance of the riverside landscape falls into two categories: hard and soft water's edges. The former consists of sheer concrete revetments and largely paved riverbanks, integrated with small-lot green places and meandering paths for cyclists and pedestrians (Figure 17). This mainly involves in-channel concrete construction and a limited capacity to support water-permeable land surfaces, wildlife habitats and biodiversity.

Soft water's edges include grassy gentle slopes, natural-looking buffer strips and natural-substrate revetments (e.g., cemented gravels and boulders), supported by gravel river beds, low stone weirs and meandering paths for cyclists and pedestrians (Figure 18). Compared to the hard edges, this approach such as the riverside area of Sinshih Park offers increased environmental and social benefits in a densely-urbanized area. Fieldwork shows river pool-riffle sequences and small sandbanks being reinstated to support good aquatic wildlife habitats and biodiversity. The planting scheme-based on a mix of Taiwanese indigenous (e.g., Koelreuteria elegans) and non-indigenous tree species (e.g., Delonix regia)—supports meandering river features that enhance the river's natural values (Figure 19). Using two types of edge for the watercourse shows a combination of urban river and landscape management strategies. However, the street furniture, paving, vegetation and environmental quality still require considerable maintenance to function properly. 
Mixed use property

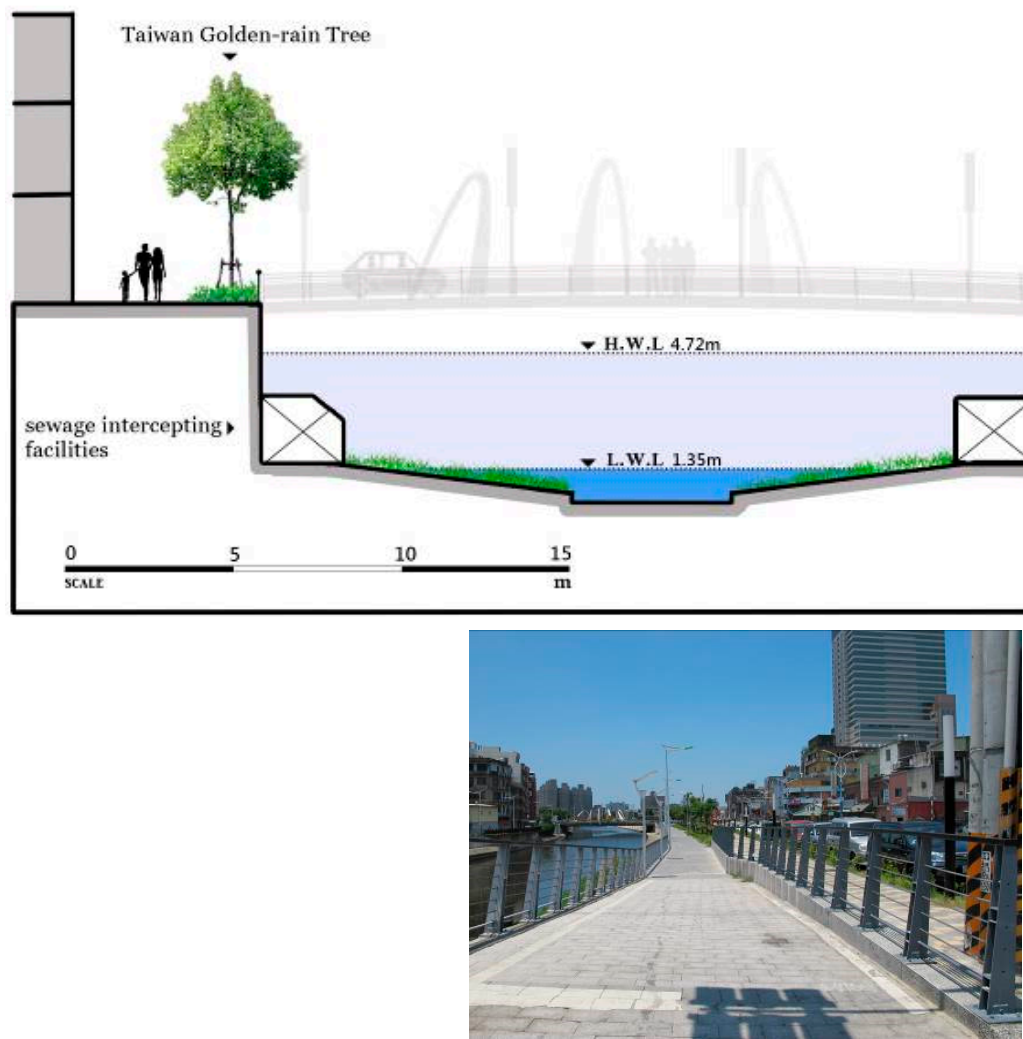

Transport

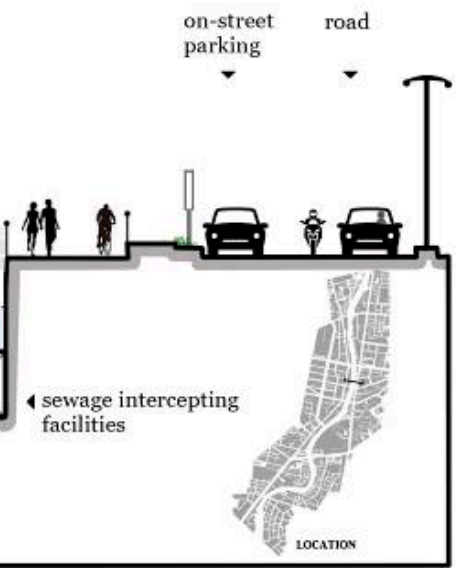

Figure 17. The Laojie River cross-section with hard water's edges near Chungsing Bridge.

Mixed use property

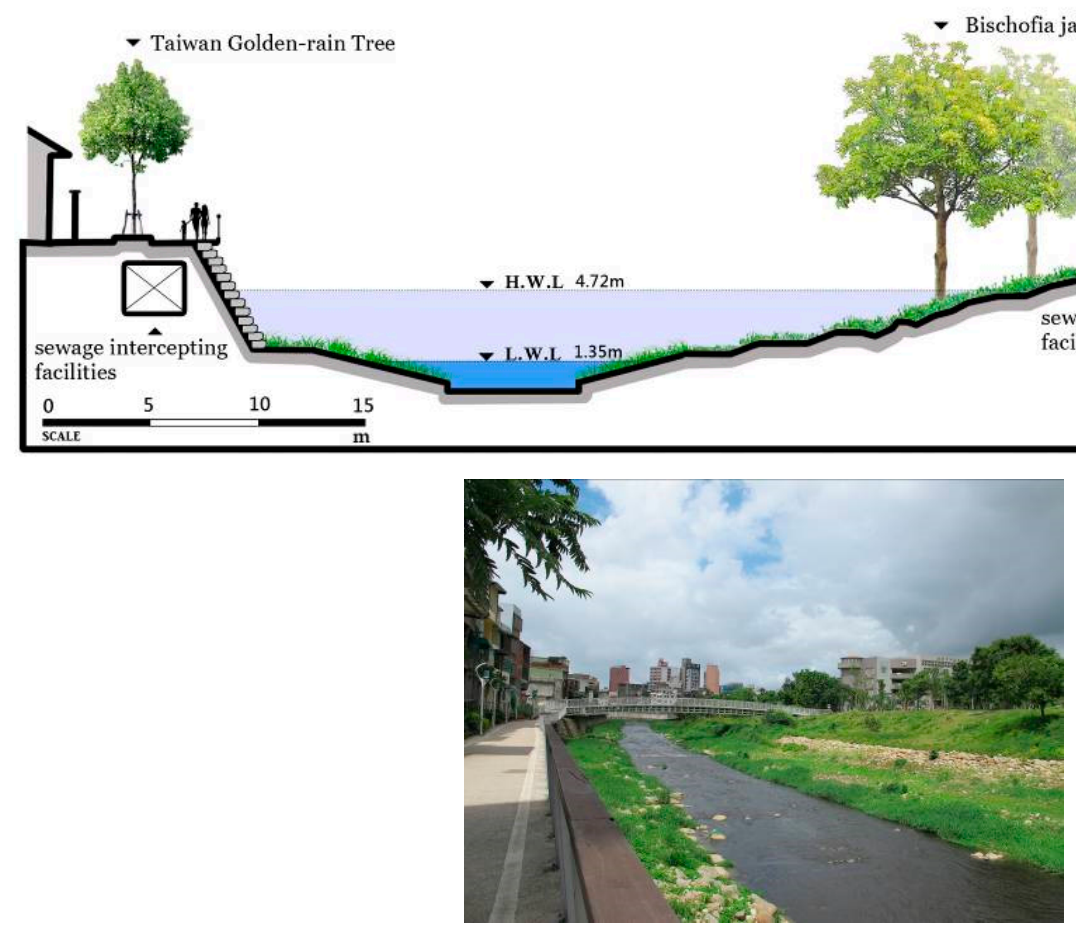

\section{Recreation}

Figure 18. The Laojie River cross-section with soft water's edges near Sinshih Park. 


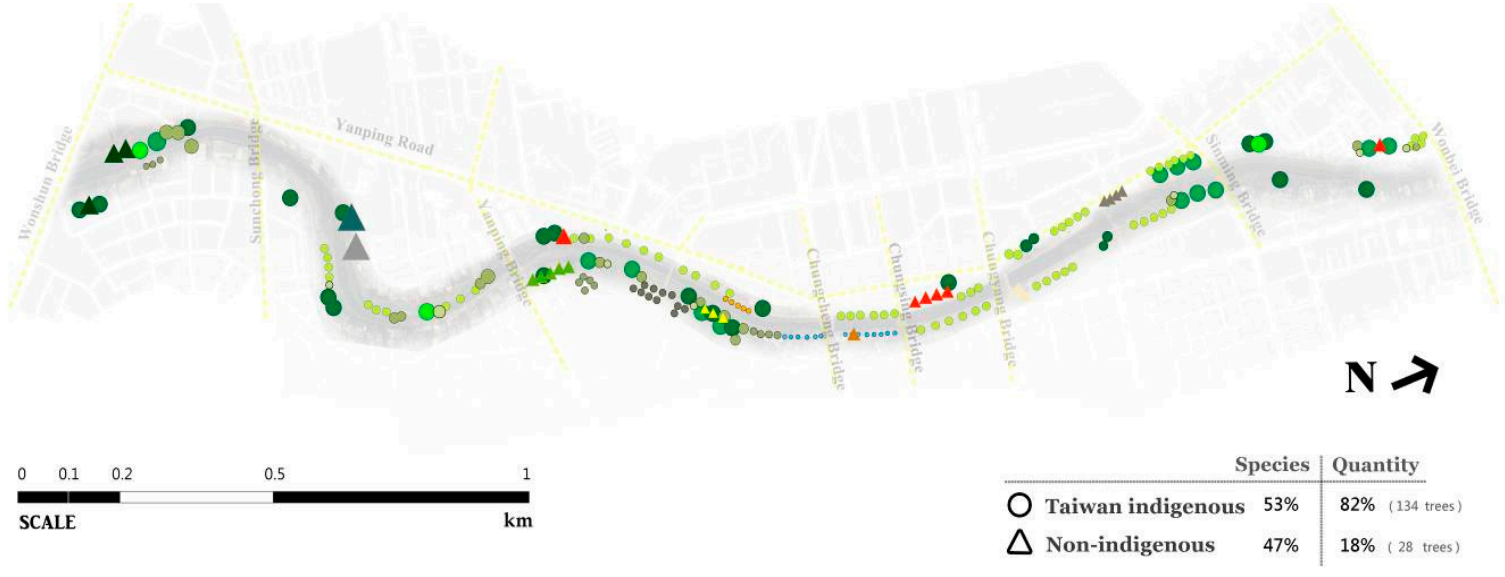

$\begin{array}{llll}\text { Acacia confusa } & \text { Fraxinus griffithii } & \Delta \text { Araucaria excelsa } & \Delta \text { Delonix regia } \\ \text { Broussonetia papyrifera } & \text { Koelreuteria elegans } & \Delta \text { Araucaria cunninghamii } & \Delta \text { Ficus elastica } \\ \text { Bischofia javanica } & \text { Liquidambar formosana } & \Delta \text { Alstonia scholaris } & \Delta \text { Haematoxylum campechianum } \\ \text { Cinnamomum camphora } & \text { Magnolia coriacea } & \Delta \text { Bombax ceiba } & \text { Magnolia grandiflora } \\ \text { Ficus microcarpa } & \text { Zelkova serrata } & \Delta \text { Cassia fistula } & \end{array}$

Figure 19. The planting design map of the Laojie River.

Third, concerning on-site treatment and sewage-intercepting facilities, the insufficiently-treated wastewater from riparian domestic, commercial and industrial premises is identified as this river's largest source of pollution [35]. The completion rate of sanitary sewer infrastructure, both basin-wide (2.8\% by the end of 2011) [65] and city-wide (45.16\% by the end of 2015) [66], has not expanded sufficiently to serve the river basin's growing population and development activities. According to TYCG [67], the Laojie River's pollution index (RPI) was 4.6-6.4, i.e., a medium-to-high level of water pollution, before the commencement of the improvement plan. The riparian residents suffered from the river's poor water quality for many years ([62], IV1*). In order to alleviate the gap between water infrastructure and environmental management in the urban river corridor, the local authority has invested more than NT \$440 million (about US \$14 million) in two main water quality improvement strategies: (1) an on-site gravel contact oxidation treatment system under Sinshih Park; and (2) riverside sewage-intercepting facilities between Wonshun and Sinming Bridges $[68,69]$.

Using a microorganisms on gravels contact oxidation process, a maximum 30,000 CMD (Cubic Meters per Day) of water could be treated including 21,500 CMD intercepted from the upstream river water and $8500 \mathrm{CMD}$ from the riparian neighbourhood's wastewater intercepted between Wonshun and Yanping Bridges. Water treated in this way is discharged back into the river to increase the downstream water quantity and quality [70]. Besides, extensive riverside sewage-intercepting facilities have been built between Yanping and Sinming Bridges to prevent insufficiently-treated municipal wastewater from draining into the river, especially the originally culverted stretch. These facilities are designed to intercept a maximum of 8777 CMD wastewater. Unfortunately, such intercepted wastewater is discharged downstream into the river after Sinming Bridge $[68,69]$. This is because the construction of the designated wastewater treatment plant has become bogged down by political issues [71]. This indicates that the strategic placement of riverside sewage-intercepting facilities in this stretch is aimed at supporting culvert-removal and riverside landscape improvement. However, the downstream area still experiences poor water quality, despite large recent investments in the improvement works.

For local communities, the Laojie River restoration outcomes have been generally favourable (IV1*]. Interviewee IV3, who is a senior landscape architect, said: 
"Besides flood prevention, the restoration project mostly relates to the multi-functional benefits of recreation and landscape. This seems to effectively respond to the expectations of local people living in cities such as the Laojie River corridor ... although water quality has been an issue that needs to be tackled, and the work done in an ecological sense is still disappointing in my view."

Following the above, important issues related to the research findings will be further discussed. They include: (1) using the Cheonggyecheon Stream as a frame for river restoration in Taiwan; and (2) flood-risk communication and the social aspects of river restoration.

\section{Discussions}

\subsection{The Cheonggyecheon Stream as River Restoration Framing in Taiwan}

Government officials in Taiwan's major municipalities, like Taoyuan, see the quest for liveable cities as a magnet for investment and tourists. Besides an international airport, a high speed rail station and a metropolitan transit system (under construction), Taoyuan has established national status by developing green infrastructure. The Laojie River, as the city's principal waterway, is the main focus of such development in the government plan, and its restoration expectation is known as "the Cheonggyecheon Stream of Taoyuan".

The Cheonggyecheon Stream restoration project was completed in Seoul, South Korea in 2005. Several similarities exist between the two restoration projects, such as their type (open space), former role (drainage), location (a densely-urbanized area), climatic conditions (flood-prone) and size (less than $6 \mathrm{~km}$ ). They both demonstrate a paradigm shift in river management, from a single-objective, drainage-oriented approach to one that appreciates the importance of functioning ecosystem services and people's quality of life. Through demolishing constructions built above a historic stretch and improving waterside landscapes, the two city-centre projects reintroduce landscape aesthetics and recreational value. Economically, like the Cheonggyecheon Stream where development capital has been invested and property prices have increased at double the rates in other areas of Seoul [72], the Laojie River has catalysed local economic growth and development that had languished since the 1990s $[73,74]$. Figure 11 shows the riverside luxury residential property whose price has risen by $20 \%-50 \%$.

Nevertheless, it could be argued that the Laojie River project is only partially successful because it failed to deal with water quality, biodiversity and maintenance. The on-site gravel contact oxidation treatment system under Sinshih Park and sewage-intercepting facilities along the river aim to mitigate water pollution. However, a lack of supporting sanitary sewer infrastructure in the river basin (e.g., a treatment plant to deal with the intercepted wastewater) still affects water quality and ecological value and creates serious environmental risks downstream. Moreover, the upstream water quantity exceeds the capacity of the contact oxidation treatment system, and the blockage of water inlets, outlets and pipes compromises the river-related wastewater treatment systems. Both problems negatively affect river water quality. In line with WRA [56] and Yang [63], pollution in the Laojie River remains low to medium despite the post-2011 improvements. Obviously, such gravel contact oxidation and sewage-intercepting methods are short-term strategies with a limited effect on water quality that require integration into the long-term, basin- and city-wide sanitary infrastructure plans. TYCG has produced a major plan (NT $\$ 16,200$ million, about US $\$ 511$ million) to increase the completion rate of basin-wide sanitary sewer systems to $40 \%$ by 2030 [68,69]. Like the Cheonggyecheon Stream [75], such constructions are time-consuming and costly, but needed.

Maintenance is a crucial factor in the long-term feasibility and success of river space design [14]. Regular maintenance involves disposing of rubbish, cleaning pavements, preserving landscape, repairing facilities and other related works [76]. Nevertheless, inadequate maintenance has rendered the improved street furniture, pavements and vegetation incapable of operating effectively, with in-channel rubbish damaging the revitalized river's environmental quality by blocking water channels 
and pipes to the wastewater treatment systems. Corresponding to a recent newspaper report [77], the fieldwork identified some riverside green places that were full of weeds with some decorative lighting being out of order, thereby damaging the ambiance of riverside recreational areas. As an example, in the Chungkang drainage channel in New Taipei City, also known as the "Cheonggyecheon Stream of Taipei" [78], removing in-channel silt and rubbish has been vital in maintaining the waterway's water quality and quantity [79]. A river restoration project's post-development stage requires sufficient and regular maintenance (e.g., mowing, rubbish clean-up, repairing and reseeding) to sustain its functions and uses. Moreover, while Taiwan's local authorities usually allocate relatively small budgets for the maintenance of river projects, local NGOs and communities are widely regarded as a solid, bottom-up force supporting urban river space as a multi-functional natural resource by regular cleaning-up, disposing of rubbish and environmental monitoring [42]. This shows the lack of a sound official post-restoration monitoring measure to assess and report the effectiveness of restoration efforts, reinforcing previous studies indicating that river restoration has largely been done but with no process to evaluate its actual performance $[16,25,26,31]$.

"Wish every city has a 'Cheonggyecheon Stream'" was used by the Taiwanese Environmental Protection Agency (TEPA) to publicize the goal of its river redevelopment policy at a recent national workshop on urban river restoration in Taipei [80]. This shows the increasing popularity of the Cheonggyecheon Stream as an exemplar for river restoration in Taiwan, e.g., promoting the current "New Luchuan River Waterfront Corridor Project" as "the Cheonggyecheon Stream of Taichung" by the Taichung City Government (TCCG) [81]. Overall, the research findings show that local people are generally supportive of the Laojie River restoration project. Although water quality and ecological value remain problematic and de-culverting may raise local concerns about potential flooding, the negative effects seem to be compensated for by the positive effects on landscape values and recreational opportunities within the area. The research reveals that the Cheonggyecheon Stream, as a frame for river restoration, provides people with an example of successful river restoration, and this seems effective. This may be because South Korea is close to Taiwan so that the Cheonggyecheon Stream can be easily visited and the potential benefits for restoring rivers in densely-urbanized areas readily inspected.

\subsection{Flood-Risk Communication and the Social Aspects of River Restoration}

Floods are the most frequent and catastrophic weather-related disaster in Taiwan and the rising risk of flooding is predominantly tackled by focusing on one objective: draining the water as quickly as possible. While hard-engineered watercourses remain widely trusted in Taiwan's dense, flood-prone urban areas [32], it is inevitable that local residents near the Laojie River worry about potential floods after culvert-removal, echoing a study by Tunstall et al. [29]. People's flood-risk perception is real, and therefore understanding it and its roots is crucial when implementing river restoration projects. The Laojie River case shows the importance of flood-risk communication between government officials and lay people. Particularly, while officials generally quote theories and statistical data to assess and explain risks to the public, the public judge risks depending mainly on qualitative considerations, such as the seriousness of the consequences, the sensation of flood control, and recent flood events and their perceived frequency [82].

A misunderstanding of officials' professional language by lay people is found in the Laojie River case. A "100-year return period" flood is a specific flood prevention requirement for the new river cross-section of the de-culverted area. However, this could lead people to think that a flood will happen once every 100 years, or the chances of such a flood happening during a 100-year period are $1 \%$, when it actually means a $1 \%$ chance of flooding occurring in any given year regardless of when it last did so, thus a "100-year return period" flood could occur twice in a short period of time. Hence, people's difficulty in comprehending the probability of flooding may lead to a misunderstanding of flood risk [83]. More significantly, with climate changes and rapid urbanization, flooding is likely to increase in size and frequency, causing considerable uncertainty in urban water management [84]. 
Hence, the return period for a particular magnitude flood event, based on past records can change over time [85]. While the probability of a flood occurring is non-stationary, it seems to mislead people about the estimated recurrence interval between flood events of a similar size or intensity. It is suggested that the expression of cumulative probability (e.g., there is a $26 \%$ probability of a flood within 30 years), rather than the probability in a single year (e.g., there is a $1 \%$ probability of a flood each year), can raise people's risk awareness and willingness to take actions for preventing the hazard, even though these are equivalent [86].

Besides the above suggestion that the use of plain language between the government and the public would lessen the gap in the communication of risk, the research has reinforced the need for more different ways of allowing people to become involved in flood prevention and to develop a greater mutual understanding and consensus regarding complex river restoration. Underpinned by Boon's five river restoration dimensions [22], it is argued that the combined effects of passive participation (e.g., through letters, leaflets, noticeboards, newsletters, newspapers, radio and television) and active participation (e.g., formal forums, workshops and fieldtrips) could be socially significant, in terms of addressing motivation and expectations of river restoration, considering the spatial connectivity and functioning within the river/catchment system, describing both the importance of river history and the requirement of post-restoration assessment, explaining the river engineering techniques currently utilized on both river channels and adjacent lands, and presenting river restoration with culvert-removal and a wider range of benefits as an alternative to redeveloping urban piped rivers.

Flood management has increasingly focused on more integrated strategies (e.g., insurance as a risk-transfer instrument to complement existing flood protection measures) aiming for both flood prevention and the alleviation of flood impacts [87]. In Taiwan, people living in flood-risk-prone areas (e.g., the Laojie River corridor) rely heavily on river engineering works, rather than voluntarily undertaking mitigation measures, thereby increasing their vulnerability to floods. As an example, given the rising importance of risk perception and awareness in promoting private precautionary behaviour, Taipei City Government established on-line flood maps [88] confirming the public's right to know such information, and the need for the growing population at risk to undertake private mitigation measures and reduce vulnerability. Nevertheless, the flood map system has been criticized for its complex interface and incomprehensible contents for ordinary people [89]. More broadly, the effect of the release of flood-related information on property prices in flood-risk-prone areas is a concern [90]. However, it is argued that property values should depend on wide-ranging and complicated factors and the government usually invests heavily in improving the civic green infrastructure systems in higher-risk areas, which often increases property prices. The riverside luxury residential property of the Laojie River is an example.

Overall, flood mapping with probabilistic information is widely used, such as the recent EU Flood Directive (2007/60/EC) for flood-risk communication, but the method of presenting data clearly and understandably to the general public remains a challenge. Based on two- and three-dimensional visualizations and dynamic simulations, the main types of flood maps cover traditional paper maps, digital (interactive) maps, and map-based information systems [91]. Although most hazard and risk maps are devised for scientists, researchers, experts, insurers and authorities for specific uses, the development of web-based applications, open-access and open-source technology and Internet availability and accessibility can support public access to risk information [92]. In line with previous studies $[29,30]$, the research reinforces that the social aspect of river restoration is significant. Local people expect to be involved in the changes in their rivers. Rather than simply the supply and passive uptake of information, a wide, practical pre- and post-restoration involvement is anticipated. Public participation should be at different levels with different resources to provide people with as many chances as possible to be involved in the way that suits them. River restoration and flood-risk communication is not merely one-way (top-down) from the experts to the lay people. For future river restoration action, therefore, the key issue may lie in the establishment of explicit and assessable social 
objectives, which are integrated with other scientific objectives to foster a better evaluation of river restoration implementation.

\section{Methodological Reflections}

The research findings were based on a particular data-collection period (August 2014 to September 2015) and a particular context (the Laojie River restoration). Due to time constraints and limited resources, the study was unable to include local riverside residents' opinions. Had their views been included during the data-collection stage, the issues that emerged could have been further developed from a broader perspective. However, following Bryman [93] and Trochim [94], the thorough description of the detailed evidence from fieldwork, interviews and document reviews on which this research relies increases the transferability of the qualitative findings.

\section{Conclusions}

Urban river management has experienced a paradigm shift from a long-established debate about the drainage-oriented, flood defence approach to a new debate on river restoration that appreciates the importance of river multi-functionality involving ecology, landscapes and ecosystem services. The Laojie River in Taoyuan City is a recent significant case of changing a channelized, culverted flood-control watercourse into a publicly accessible green infrastructure corridor. While this river project is widely regarded as the first extensive and successful river restoration project in a densely-urbanized, flood-prone area in Taiwan, its actual performance is rarely examined in any depth. This paper presents findings on the practical factors involved in the practice of river restoration and their implications for urban river management. The main findings are:

(1) River restoration with culvert-removal was generally supported by local people for improving environmental quality, but raised concerns about potential flooding. This may arise from different perceptions and the miscommunication of flood risk that occurred between the experts and the general public.

(2) Both hard and soft water's edges formed the improved riverside landscapes, showing a mix of river management methods in a densely-urbanized area. Adequate maintenance was needed to ensure effective functionality.

(3) An integration of an on-site gravel contact oxidation treatment system and riverside sewage-intercepting facilities was adopted to improve the river water quality, but proved ineffective without support from a basin-wide sanitary sewer infrastructure.

(4) People's positive attitudes towards river restoration were mainly related to landscape aesthetics and recreational value, although water pollution and ecological degradation remained problematic.

The findings indicate that the Laojie River project is only partially successful as it failed to deal with water quality, biodiversity and maintenance; nevertheless, such negative outcomes seem to be compensated for by the favourable effects on landscape values and recreational opportunities. It is revealed that the use of the Cheonggyecheon Stream in South Korea as the frame for river restoration seems effective in giving people a distinct example of a successful outcome. The local public frames river restoration expectations in their own terms, mainly based on the prevention of flooding and the improvement of recreational and aesthetic values in the case of the Laojie River. According to the three dimensions of the most effective river restorations by Palmer et al. [26], the Laojie River project may only achieve stakeholder success that responds to human needs through the outcomes of flood prevention, landscape aesthetics, economic benefits and recreation.

Furthermore, the research has reinforced the importance of flood-risk communication and the social aspects of river restoration, particularly in densely-urban, flood-prone areas, as it is implied that the general public is not confident about green-engineered solutions because they think that their flood risk is greater than for the hard-engineered systems. Even though integrated flood management 
using flood mapping with probabilistic data is widely promoted, the way of intelligibly presenting information to the general public remains a challenge for flood-risk communication. Some positive suggestions for helping the understanding of the related data and encouraging the adoption of mitigation measures include the use of plain language, cumulative probability and people-friendly, web-based map systems. This should reduce their concerns about flood risk and their vulnerability to floods. Moreover, local people anticipate practical, continuous and extensive participation before and after project implementation, with a variety of types of involvement and mechanisms (passive and active) to achieve better mutual understanding and consensus regarding complex river restoration. Different measures may be expected in different localities. The importance is to foster a reciprocal relationship between citizens and the government and the development of clear, assessable, social and scientific objectives for judging the success of river restoration.

Acknowledgments: This study was supported by the research grant from the Ministry of Science and Technology, Taiwan (MOST 103-2410-H-033-034).

Conflicts of Interest: The authors declare no conflict of interest.

\section{Appendix A}

\section{Appendix A.1. Accessibility}

1. Does it provide visitors with adequate access to river space?

2. Does it supply view corridors to connect the city and river?

3. Does it create public open space (e.g., corners and parks) where visitors can sit, look across water or enjoy outdoor activities?

4. Does it give visitors convenient connections with public transport systems?

\section{Appendix A.2. Activities}

5. Does it provide diverse leisure activities (e.g., cycling, jogging or strolling)?

6. Does it supply appropriate riverside economic activities (e.g., shops, cafes)?

\section{Appendix A.3. Public Facilities}

7. Does it provide sufficient street furniture (e.g., benches and signage) to reflect user needs?

8. Does it install safety and traffic signage and installations to help visitors prevent accidents?

9. Does it have acceptable maintenance services (e.g., repair)?

\section{Appendix A.4. Environmental Quality}

10. Does it effectively improve water quality?

11. Does it productively enhance municipal sewage treatment?

12. Does it regularly conduct environmental clean-up and rubbish disposal?

\section{Appendix A.5. Ecological Value}

13. Is it developed in diverse forms (e.g., irregular margins or banks) to make the water's edge and waterside wildlife varied?

14. Does it provide valuable green vegetation and planting?

15. Does it use ecological engineering techniques (e.g., low weirs, deflectors or revetments) to support in-channel wildlife habitat features locally (e.g., pool-riffle sequences)?

\section{Appendix A.6. Flood Prevention}

16. Is flood protection construction (e.g., embankments) built with sheer concrete revetments?

17. Does it employ sustainable drainage methods (e.g., permeable pavements) to enhance rainwater infiltration? 
18. Does it provide multi-functional purposes (e.g., a combination of amenity and drainage)?

\section{References}

1. Intergovernmental Panel on Climate Change (IPCC). Climate Change 2014: Synthesis Report; IPCC: Geneva, Switzerland, 2015.

2. UN-Habitat. Enhancing Urban Safety and Security: Global Report on Human Settlements 2007; Earthscan: London, UK, 2007.

3. Prominski, M.; Stokman, A.; Zeller, S.; Stimberg, D.; Voermanek, H. River Space Design: Planning Strategies, Methods and Projects for Urban Rivers; Birkhauser: Basel, Switzerland, 2012.

4. Turner, T. Landscape Planning; Hutchinson: London, UK, 1987.

5. Rouse, D.C.; Bunster-Ossa, I.F. Green Infrastructure: A Landscape Approach; American Planning Association: Washington, DC, USA, 2013.

6. Goode, D. Green Infrastructure: Report to the Royal Commission on Environmental Pollution. 2006. Available online: http:/ /www.greeninfrastructurenw.co.uk/climatechange/doc.php?docID=168 (accessed on 30 July 2015).

7. Wong, T.H.F.; Brown, R.R. The water sensitive city: Principles for practice. Water Sci. Technol. 2009, 60, 673-682. [CrossRef] [PubMed]

8. Yu, K.J. Two rivers in a distant place. Landsc. Archit. Front. 2013, 1, 7.

9. White, I.; Howe, J. The mismanagement of surface water. Appl. Geogr. 2004, 24, 261-280. [CrossRef]

10. Chou, R.J. Addressing watercourse sanitation in dense, water-pollution-affected urban areas in Taiwan. Environ. Urban. 2013, 25, 523-540. [CrossRef]

11. Gregory, K.J.; Chin, A. Urban stream channel hazards. Area 2002, 34, 312-321. [CrossRef]

12. Pinkham, R. Daylighting: New Life for Buried Streams; Rocky Mountain Institute: Boulder, CO, USA, 2000.

13. Jones, P.; Macdonald, N. Making space for unruly water: Sustainable drainage systems and the disciplining of surface runoff. Geoforum 2007, 38, 534-544. [CrossRef]

14. Dreiseitl, H.; Grau, D. (Eds.) New Waterscapes: Planning, Building and Designing with Water; Birkhauser: Basel, Switzerland, 2005.

15. Adams, W.M.; Perrow, M.R.; Carpenter, A. Conservatives and champions: River managers and the river restoration discourse in the United Kingdom. Environ. Plan. A 2004, 36, 1929-1942. [CrossRef]

16. Cowx, I.; Angelopoulos, N.; Noble, R.; Slawson, D.; Buijse, T.; Wolter, C. Measuring Success of River Restoration Actions Using End-Points and Benchmarking. Available online: http://www.reformrivers. $\mathrm{eu} /$ measuring-success-river-restoration-actions-using-end-points-and-benchmarking (accessed on 9 November 2016).

17. Cengiz, B. Urban river landscapes. In Advances in Landscape Architecture; Ozyavuz, M., Ed.; InTech: Rijeka, Croatia, 2013.

18. Haase, P.; Hering, D.; Jahnig, S.C.; Lorenz, A.W.; Sundermann, A. The impact of hydromorphological restoration on river ecological status: A comparison of fish, benthic invertebrates, and macrophytes. Hydrobiologia 2013, 704, 475-488. [CrossRef]

19. Kamp, U.; Binder, W.; Hölzl, K. River habitat monitoring and assessment in Germany. Environ. Monit. Assess. 2007, 127, 209-226. [CrossRef] [PubMed]

20. Bernhardt, E.S.; Palmer, M.A.; Allan, J.D.; Alexander, G.; Barnas, K.; Brooks, S.; Carr, J.; Clayton, S.; Dahm, C.; Follstad-Shah, J.; et al. Synthesizing U.S. river restoration efforts. Science 2005, 308, 636-637. [CrossRef] [PubMed]

21. Beechie, T.; Pess, G.; Roni, P. Setting river restoration priorities: A review of approaches and a general protocol for identifying and prioritizing actions. N. Am. J. Fish. Manag. 2008, 28, 891-905. [CrossRef]

22. Boon, P.J. River restoration in five dimensions. Aquat. Conserv. Mar. Freshw. Ecosyst. 1998, 8, $257-264$. [CrossRef]

23. Hobbs, R.J. Setting effective and realistic restoration goals: Key directions for research. Restor. Ecol. 2007, 15, 354-357. [CrossRef]

24. Woolsey, S.; Capelli, F.; Gonser, T.; Hoehn, E.; Hostmann, M.; Junker, B.; Paetzold, A.; Roulier, C.; Schweizer, S.; Tiegs, S.D.; et al. A strategy to assess river restoration success. Freshw. Biol. 2007, 52, 752-769. [CrossRef] 
25. Jähnig, S.C.; Lorenz, A.W.; Hering, D.; Antons, C.; Sundermann, A.; Jedicke, E.; Haase, P. River restoration success: A question of perception. Ecol. Appl. 2011, 21, 2007-2015. [CrossRef] [PubMed]

26. Palmer, M.A.; Bernhardt, E.S.; Allan, J.D.; Lake, P.S.; Alexander, G.; Brooks, S.; Carr, J.; Clayton, S.; Dahm, C.N.; Shah, J.F.; et al. Standards for ecologically successful river restoration. J. Appl. Ecol. 2005, 42, 208-217. [CrossRef]

27. Dufour, S.; Piegay, H. From the myth of a lost paradise to targeted river restoration: Forget natural references and focus on human benefits. River Res. Appl. 2009, 25, 568-581. [CrossRef]

28. Buijs, A.E. Public support for river restoration: A mixed-method study into local residents' support for and framing of river management and ecological restoration in the Dutch floodplains. J. Environ. Manag. 2009, 90, 2680-2689. [CrossRef] [PubMed]

29. Tunstall, S.M.; Penning-Rowsell, E.C.; Tapsell, S.M.; Eden, S.E. River restoration: Public attitudes and expectations. J. Chart. Inst. Water Environ. Manag. 2000, 14, 363-370. [CrossRef]

30. Eden, S.; Tunstall, S. Ecological versus social restoration? How urban river restoration challenges but also fails to challenge the science-Policy nexus in the United Kingdom. Environ. Plan. C Gov. Policy 2006, 24, 661-680. [CrossRef]

31. Wohl, E.; Angermeier, P.L.; Bledsoe, B.; Kondolf, G.M.; MacDonnell, L.; Merritt, D.M.; Palmer, M.A.; Poff, N.L.; Tarboton, D. River restoration. Water Resour. Res. 2005, 41, W10301. [CrossRef]

32. Chou, R.J. Exploring the quasi-naturalistic landscaping design of a Taiwanese culverted urban stream. Landsc. Res. 2013, 38, 347-367. [CrossRef]

33. Taiwanese Environmental Protection Administration (TEPA). Completion of improving six urban watercourses. Environ. Policy Mon. 2013, 16, 5-6.

34. Lee, H.Y. City Revolution Should Depend on Citizen Participation. 2015. Available online: http://www. yucc.org.tw/news/domestic/20150110-1 (accessed on 3 August 2015).

35. Taoyuan City Government (TYCG). Taoyuan Laojie River Improvement Plan. 2011. Available online: http://www.lj-river.com.tw/ (accessed on 4 August 2015).

36. Taoyuan City Government (TYCG). Urban Regeneration Plan: Chungli Laojie River; TYCG: Taoyuan, Taiwan, 2011.

37. Water Resources Agency (WRA). Hydrological Yearbook of Taiwan 2007; WRA: Taipei, Taiwan, 2008.

38. Tu, J.Y.; Yu, J.Y.; Chou, C. Taiwan's Climate; Walkers: Taipei, Taiwan, 2003.

39. Hsu, S.K. An Introduction to Sustainable Development of Water Resources; WRA: Taipei, Taiwan, 2000.

40. Ministry of the Interior (MOI). Statistical Yearbook. 2015. Available online: http://www.moi.gov.tw/stat/ year.aspx (accessed on 11 August 2015).

41. Water Resources Agency (WRA). Evaluation for Process, Impel and Execution of Ecotechnology; WRA: Taipei, Taiwan, 2006.

42. Chou, R.J. The problems of watercourse redevelopment: Disseminating new knowledge about flood risk perception in Taiwan's densely populated, typhoon-affected urban areas. Int. Dev. Plan. Rev. 2012, 34, 241-267. [CrossRef]

43. Water Resources Agency (WRA). References to Ecological Engineering. 2014. Available online: http: / / www.wranb.gov.tw /ct.asp?xItem=2685\&ctNode=833\&mp=5 (accessed on 13 August 2015).

44. Wang, H.W. Post-Project Appraisals and Adaptive Management on River Restoration in Taiwan. Report Prepared for National Science Council (NSC 98-2221-E006-237); 2010. Available online: http:/ / statistics. most.gov.tw/was2/award/AsAwardMultiQuery.aspx (accessed on 21 July 2016).

45. Wang, Y.J. The Past, Present and Future of Taiwan's River Environmental Improvement. 2014. Available online: http:/ /trrn.wra.gov.tw/trrn/darenColumn/view.do?id=14785f44af0000009a0c (accessed on 14 August 2015).

46. Council for Economic Planning and Development (CEPD). Challenge 2008-National Development Plan; CEPD: Taipei, Taiwan, 2005.

47. Lee, S.H.; Hou, J.S.; Chen, Y.J. Public preferences towards landscape design of urban riverfronts. J. Landsc. 2000, 6, 55-69.

48. Lee, S.H.; Yang, W.L. A comparison study of bioengineering streambank types. J. Archit. 2011, 78, 61-81.

49. Public Construction Commission (PCC). Ecological Engineering Expositions. 2006. Available online: http:/ / eem.pcc.gov.tw/taxonomy/term/814 (accessed on 14 August 2015). 
50. Wang, H.W. River Restoration in Taiwan: Past, Present and Future. 2013. Available online: http://trrn.wra. gov.tw/trrn/darenColumn/view.do?id=13e8db32e1700000aef7 (accessed on 14 August 2015).

51. Fang, C. (Ed.) Waterfront Landscapes; Design Media Publishing Limited: Hong Kong, China, 2012.

52. Construction and Planning Agency (CPA). Land Use in Urban Waterfronts and Water Accessibility: A Case Study of the Danshui River; CPA: Taipei, Taiwan, 1998.

53. Kuo, M. Green and Blue Network: The Theory and Practice of Sustainable Landscape Planning; Chan's Arch Books: Taipei, Taiwan, 2003.

54. Ching, C.J.; Chang, G.M.; Hu, J.; Fu, Y.T. The water pollution control and remedial strategy of the Laojie River. Environ. Bull. 2012, 16,1-13.

55. Water Resources Agency (WRA). An Examination Report on the Laojie River Corridor; WRA: Taipei, Taiwan, 2009.

56. Water Resources Agency (WRA). The Restoration of the Laojie River. 2014. Available online: http://trrn. wra.gov.tw/trrn/restorationCase/index.do (accessed on 5 September 2015).

57. The Liberty Times. Mayor Wu Inspected the Laojie River's Lighting Walls before His Retirement. 2014. Available online: http://news.ltn.com.tw/news/life/breakingnews/1185699 (accessed on 7 September 2015).

58. Taoyuan City Government (TYCG). Introduction to Cross-Sectoral Collaboration, Taoyuan Laojie River Improvement Plan. 2011. Available online: http://tunyang2011.pixnet.net/blog/category/2748621 (accessed on 7 September 2015).

59. The United Daily News. The Schedule of De-Culverting the Laojie River Is Confirmed. Available online: http:/ /udn.com/NEWS/DOMESTIC/DOM3/6101423.shtml (accessed on 15 September 2015).

60. Taoyuan City Government (TYCG). Working Report of the Department of Water Resources for Taoyuan City Council; TYCG: Taoyuan, Taiwan, 2012.

61. The Liberty Times. Local Participation as the Most Important Factor in the Improvement of the Laojie River. 2 August 2011. Available online: http://news.ltn.com.tw/news/local/paper/513210 (accessed on 20 September 2015).

62. The Epoch Times. The Improvement of the Laojie River-Good Water Quality, Good Life Quality. 2011. Available online: http://www.epochtimes.com/b5/11/7/23/n3323309.htm (accessed on 19 September 2015).

63. Yang, Y.H. Lessons Learned from an Urban River Restoration Project in Laojie River. Master's Thesis, National Cheng Kung University, Tainan, Taiwan, 2014.

64. The United Daily News. The Laojie River Was De-Culverting in Protest. 2011. Available online: http: / / udn.com/NEWS/DOMESTIC/DOM3/6215574.shtml (accessed on 22 September 2015).

65. Taiwanese Environmental Protection Administration (TEPA). The Water Pollution Control Plan of the Laojie River; TEPA: Taipei, Taiwan, 2011.

66. Construction and Planning Agency (CPA). The Statistics of the National-Wide Completion Rate of Sanitary Sewer Infrastructure. 2015. Available online: http:/ / www.cpami.gov.tw/chinese/index.php?option=com content\&view=article\&id=9995\&Itemid=53 (accessed on 29 September 2015).

67. Taoyuan City Government (TYCG). The Water Quality Improvement Construction in Taoyuan City. 2012. Available online: http:/ /59.124.57.236/taoyuan/news.htm (accessed on 29 September 2015).

68. Huang, H.P. A New Version for Urban River Improvement; Taoyuan City Government: Taoyuan, Taiwan, 2012.

69. Li, R.W. Flood Prevention and Waterfront Development; Taipei Professional Civil Engineers Association: Taipei, Taiwan, 2011.

70. Chen, S.W.; Yeh, M.F.; Tsai, Y.C. Sinshih Park's gravel contact oxidation treatment system to improve the Laojie River. Constr. News Rec. 2014, 382, 4-14.

71. The News Lens. The Construction of Chungli Wastewater Treatment Plant Has Been Procrastinated 6 Years. 2015. Available online: http:/ / www.thenewslens.com/post/122030/ (accessed on 6 October 2015).

72. Commission for Architecture and the Built Environment (CABE). Cheonggyecheon Restoration Project. 2011. Available online: http:/ / webarchive.nationalarchives.gov.uk/20110118095356/http:/ /www.cabe.org.uk/ case-studies/cheonggyecheon-restoration-project (accessed on 10 October 2015).

73. CNA New. River Space, Green Place-People Expect the Rise of Property Prices. 2011. Available online: http:/ / www.cna.com.tw/topic/newstopic/229-2/201107230021-1.aspx (accessed on 11 October 2015).

74. Peng, S.C. Using tactics to make the city vision come true. Glob. Views Mon. 2014, 336, 159. 
75. Shin, J.H.; Lee, I.K. Cheong Gye Cheon restoration in Seoul, Korea. Civ. Eng. 2006, 159, 162-170. [CrossRef]

76. Wrenn, D.M.; Casazza, J.A.; Smart, J.E. Urban Waterfront Development; ULI-the Urban Land Institute: Washington, DC, USA, 1983.

77. The Liberty Times. A Need for the Enhancement of the Laojie River Improvement. 2015. Available online: http:/ / news.ltn.com.tw/news/local/paper/887654 (accessed on 10 October 2015).

78. New Taipei City Government (NTCG) Chungkang Drainage Channel. 2015. Available online: http://dreamriver.ntpc.gov.tw / Facility/Detail/1 (accessed on 15 October 2015).

79. Chen, S.T. A Study of the Landscape Benefit for the Chungkang Drainage Channel. Master's Thesis, National Taipei University of Education, Taipei, Taiwan, 2014.

80. The Liberty Times. Visiting the Chungkang Drainage Channel, Wish Every City Has a Cheonggyecheon Stream. 2015. Available online: http://news.ltn.com.tw/news/life/breakingnews/1393656 (accessed on 17 October 2015).

81. Taichung City Government (TCCG). New Luchuan River Waterfront Corridor Project to Bring New Life to a Central District. 2015. Available online: http://www.wrs.taichung.gov.tw/ct.asp?xItem=1519638\&ctNode= $8963 \& \mathrm{mp}=158010$ (accessed on 17 October 2015).

82. Jacobs, L.; Worthley, R. A comparative study of risk appraisal: A new look at risk assessment in different countries. Environ. Monit. Assess. 1999, 59, 225-247. [CrossRef]

83. Burningham, K.; Fielding, J.; Thrush, D. It'll never happen to me: Understanding public awareness of local flood risk. Disasters 2008, 32, 216-238. [CrossRef] [PubMed]

84. European Commission. A European Flood Action Programme. 2015. Available online: http://ec.europa.eu/ environment/water/flood_risk/consult.htm (accessed on 7 November 2015).

85. Vogel, R.M.; Yaindl, C.; Walter, M. Nonstationarity: Flood magnification and recurrence reduction factors in the United States. J. Am. Water Resour. Assoc. 2011, 47, 464-474. [CrossRef]

86. Strathie, A.; Netto, G.; Walker, G.H.; Pender, G. How presentation format affects the interpretation of probabilistic flood risk information. J. Flood Risk Manag. 2015. [CrossRef]

87. Bubeck, P.; Botzen, W.J.W.; Aerts, J.C.J.H. A review of risk perceptions and other factors that influence flood mitigation behaviour. Risk Anal. 2012, 32, 1481-1495. [CrossRef] [PubMed]

88. Taipei City Government (TPCG). Taipei City Government Launching City Flood Maps. 2015. Available online: http: / /www.gov.taipei/ct.asp?xItem=120989946\&ctNode=5158\&mp=100001 (accessed on 12 November 2015).

89. The Liberty Times. Flood Map System Difficult to Understand. 2015. Available online: http://news.ltn.com. tw/news/politics/breakingnews/1465192 (accessed on 12 November 2015).

90. CNA News. An Online Flood Map System Launched by Taipei City Government. 2015. Available online: http:/ / www.cna.com.tw/news/aloc/201509280399-1.aspx (accessed on 13 November 2015).

91. Hagemeier-Klose, M.; Wagner, K. Evaluation of flood hazard maps in print and web mapping services as information tools in flood risk communication. Nat. Hazards Earth Syst. Sci. 2009, 9, 563-574. [CrossRef]

92. Dransch, D.; Rotzoll, H.; Poser, K. The contribution of maps to the challenges of risk communication to the public. Int. J. Digit. Earth 2010, 3, 292-311. [CrossRef]

93. Bryman, A. Social Research Methods, 2nd ed.; Oxford University Press: Oxford, UK, 2004.

94. Trochim, W. Qualitative Validity. Research Methods Knowledge Base. 2006. Available online: http://www. socialresearchmethods.net/kb/qualval.php (accessed on 16 October 2016).

(C) 2016 by the author; licensee MDPI, Basel, Switzerland. This article is an open access article distributed under the terms and conditions of the Creative Commons Attribution (CC-BY) license (http://creativecommons.org/licenses/by/4.0/). 